\title{
Computers: A Private Domain for Today's Youth
}

\author{
Dr. Navneet Arora* \\ *Assistant Professor (Sociology), University Institute of Legal Studies (UILS), Panjab University, Chandigarh.
}

\begin{abstract}
Today's children comprise a generation which is truly growing digital. They have a far greater access to sophisticated technology than ever before. They carry hi-tech tools with them viz., cellular phones, play video games during and after school, and use computers for various activities. Their access to digital media has made them different in what they think, learn, shop, work, study, etc. Possession of computers at home and commercialization of this facility in the form of cyber cafes has made them active users of this technology. Interestingly and surprisingly, despite possessing computers at home, children are seen visiting cyber cafes. It means besides home, they are using other places for accessing computers. Which are those places where they access computers? What is the pull of cyber café? What is the location of computer at home and at the cyber café? These are the questions which need systematic investigation. The present paper intends to explores this issue at length.

In modern times communication technology has revolutionized the media of mass communication. Earlier communication to the masses was primarily carried through print media that included newspapers, bulletins, pamphlets and periodicals besides the public meetings, conferences etc. Now it has been replaced by communication through electronic media, which include radio, television, film shows, audio/video cassettes, computers, etc. The development of these has provided a very effective means of influencing the masses and educating the people.
\end{abstract}

The electronic media have emerged as the single most influential mode of mass communication especially for the young, for whom computer literacy has become a necessity. The computer is a fundamentally different type of medium from everything that came before. Computer is not about computing any more. It is about living. The giant central computer, the so called main frame, has been almost universally replaced by personal computers With personal computers, we have access to even more information than ever when we connect to the Internet. The internet gives us access to about 3,000 newspapers (Kawamoto 2003). Also, the World Wide Web offers access to about 2.5 billion documents (Potter 2008).

Current research suggests that teenagers are more comfortable with information and communication technologies than their parents (Center for Media Education 2001; Lenhart, Ramie and Lewis 2001; Livingstone 2001). For the first time since the introduction of the television (Center for Media Education 2001), teenagers have a better grasp of both the content and the technology of this new mass medium. The interesting aspect of internet is that not only is the information easily available to almost everyone, but it also keeps getting produced at an ever increasing rate. The historic invention of this century is computer and has made our life both easier and faster. This wonderful machine has unique features like speed, accuracy, consistency, versatility, memory, but no feelings. Because of its tremendous capacity to take up a large number of human activities, we have almost surrendered our lives to this machine. But what is important here is that the invention of the modern computer is a result of the innovative mind of human being. Today computer literacy has become an important educational qualification besides other qualifications. Initially computers were used only for computing, typing, data saving etc., but with the emergence of internet and new softwares the purposes served by computers are endless and limitless. In a conference entitled 'Principals defining Principles' on 27 $7^{\text {th }}$ April, 2005 (Times of Chandigarh, 28 ${ }^{\text {th }}$ April, 2005:2), in Chandigarh, school Principals of Chandigarh, Mohali and Panchkula agreed on a point that technology, especially IT, is an inseparable part of our lives in the knowledge society. That is precisely the reason schools are providing computer education to children. This education and information via computers has opened plethora of issues with regard to adolescents.

It is apparent that due to the desire to access information and rapid technological changes, we have seen computers move out of giant air conditioned rooms into closets, then on to desktops, and now into our laps and palms. People carry them under their arms to the parks. Commercialization of this facility in the cyber cafes has made it easier even for the so called "havenots" to be a part of the electronically informative society. Mushrooming of the cyber cafes has removed the divide between haves and havenots. Are cyber cafes meant only for those who do not possess computers? Is it so that those who can afford access to computers only in home while others access at cyber cafes? One wonders why cyber cafes remain flooded with adolescents? Adolescence is an exciting, life altering phase of one's life, which demands space, time, privacy, freedom, responsibility, opportunity to experiment and faith. Hence, for adolescents, the online realm may be 
enthusiastically adopted because it represents 'their' space, visible and similar to the peer group more than to adult policing, an exciting, marvellous and safe opportunity to conduct the social psychological task of adolescence - to construct, experiment with, and present a reflexive project of the self in a social context (Buchner, Bois-Reymond and Kruger, 1995; Giddens, 1991) as well as, for some, for flouting communicative norms and other risk-taking behaviours (Hope, 2007; Kerr and Stattin, 2000; Liau, Khoo, and Ang, 2005; Wolak, Mitchell, and Finkelhor, 2006).

Thus adolescent use of computers has much deeper implications than simply developing specific technical skills.

In this backdrop, the increased flirtation of adolescents with information technology raises some questions, i.e. where do they access the computers? especially the internet; how much time do they spend with computers? Does possessing a personal computer curb their visits to cyber cafés? What does the pull of cyber café comprise of? These are among the questions addressed in the following discussion.

\section{Methodology}

For this purpose, a study was conducted on urban adolescents in Chandigarh. Sample comprised of those respondents who had been regularly accessing computers at various places viz. cyber café, home, friends' place, computer institute, etc. Respondents were selected by using systematic random sampling. A sample of 200 respondents from four schools of Chandigarh (two government and two private) was selected. Interview schedule was prepared about computer use with the objective of obtaining information regarding the time, places visited by them for accessing computers, association between income of the family and possession, etc. was investigated.

In Chandigarh, in most of the schools computer is taught either as a compulsory or an optional subject. Every school has its own computer laboratory with trained computer teachers. Schools charge hefty computer fees from the students for providing computer education. Some of my respondents had not studied computers in their school but still could manage it very well. It is very interesting to explore as to where these adolescents have learnt to operate computers if not in school.

All the 200 respondents were of classes $10+1$ and 10+2, 68.5 per cent respondents had received computer training prior to class $10^{\text {th, }}$ while 31.5 per cent respondents had not studied computer as a subject in their previous school. The data also highlights that the percentage of female respondents who studied computers is 73 , whereas the percentage of such male respondents is 65 . The gender difference in terms of computer training is due to the types of the schools from where they had passed their $10^{\text {th }}$ class. According to the respondents, in some schools, both theory and practicals in computers were taught in the same class, whereas in others, these were introduced at different standards. Most of my respondents accessed computers when they were in $5^{\text {th }}$ class. A small proportion among them, that is 14 respondents, learnt to use computers between classes $8^{\text {th }}$ to $10^{\text {th }}$ in school. There is no fixed age at which the child is being given computer training, since our respondents started accessing at different ages and in different classes.

The Kaiser Family Foundation's recent report Kids and Media @ The New Millennium (1999) narrated that children were engrossed in media. Their lives are increasingly devoted to video game playing, browsing the internet and conversing in chat rooms. Increasingly, computers are invading both in students' homes and classrooms. Possessing a computer sounds very common these days. The researcher found that 55.5 per cent of the respondents possessed computers at home whereas 44.5 per cent did not possess a computer at home.

Another finding was that the respondents accessed computer at more than one place. Interestingly, those who possessed a computer at home, accessed it at more than one place. Table 1 gives the data on the use of computer by respondents at various places and the data show that 84.5 per cent of the total respondents had computer access at the cyber café, 55.5 per cent of them had an access to the computer at home, while 48 per cent of respondents accessed it at their friends' place and 18.5 per cent of the respondents accessed it at a computer institute. Data show that cyber café is the most popular place of accessing computer by the respondents. Data also highlight that more female respondents had joined computer institutes than male respondents. Respondents joined institutes for learning basics or advanced

Table 1Places at Which Respondents Access Computers

\begin{tabular}{|l|c|c|c|}
\hline Place & Boys & Girls & Total* \\
\hline Cyber café & 96 & 73 & 169 \\
\hline Home & 69 & 42 & 111 \\
\hline Friends' place & 54 & 42 & 96 \\
\hline Computer institute & 16 & 21 & 37 \\
\hline
\end{tabular}

* The categories are not exclusive 
Courses in computers. Joining computer courses by female respondents is very crucial as in our society 'technical competence is central to the dominant cultural ideal of masculinity, and its absence is a key feature of stereotyped feminity' (Wazcman 1991:59). Consequently, women's reluctance to be technically sound can be attributed to cultural structures which differentiate women from men. Many 'technologies of service' are gendered as female while 'technologies of power' and choice are gendered as male. British researcher Gray (1989), looking at gender and technology concludes by noting that women tend to rely upon their male partners or their children to set the timer of VCR for them. People may fear technology for a variety of reasons - for example, they may feel inadequate and incompetent when faced with technology. For these technofobes, fear of technology can lead to a sense of helplessness and hopelessness. In contrast, men may be reluctant to use irons, vacuum cleaners, food processors or microwaves (ibid 1989), but they are unlikely to see this as a problem of personal inadequacy, rather as an issue of gender- such technologies are female ones. See, how easily we have demarcated the techonology as 'technologies of men' and 'technologies of women' and these demarcations indicate that man is for the outside world and woman is for the home.

As far as visiting different places for accessing computers by male and female respondents was concerned, both enjoyed an equal access to computers

Table 2 Multiple Locations at which Respondents Access Computers

\begin{tabular}{|l|c|c|c|}
\hline Location & Boys & Girls & Total \\
\hline Cyber café & 07 & 14 & 07 \\
\hline Friends' place & - & 07 & 13 \\
\hline Home & 08 & 05 & 40 \\
\hline $\begin{array}{l}\text { Cyber café + } \\
\text { Friend }\end{array}$ & 23 & 17 & 53 \\
\hline $\begin{array}{l}\text { Cyber café + home } \\
\text { Cyber café +computer } \\
\text { institute }\end{array}$ & 32 & 21 & 06 \\
\hline Friends' place + home & 05 & 01 & 05 \\
\hline Multiple places* & 04 & $\mathbf{8 9}$ & 55 \\
\hline Total & 32 & $\mathbf{1 1 1}$ & 23 \\
\hline
\end{tabular}

* multiple places means respondents were accessing computer at more than two places.

At all the places. There were four main locations used by respondents for accessing computer, viz. cyber café, home, friends' place and computer institute.

In Table 2 researcher has attempted a detailed analysis of the places where respondents accessed computers.

The objective of tabulating data in this manner is to acquaint ourselves with some of the hidden facts regarding the number of places used by the respondents for accessing computers. Data in Table 2 gives the details of places used by respondents for accessing computers and it comes out that 26.5 per cent of the respondents used computers both at cyber cafe as well as at home. It means that the respondents who possessed computers at home were also accessing them at the cyber cafes. This further reveals that possessing a computer at home will not stop the users for going to cyber cafés. Respondents revealed various reasons for using computers at cyber cafés like 'no internet connection of computer at home', ' inflated telephone bill', 'nice change', air conditioned ambience, 'privacy' etc.. Data also show that 20 per cent of the respondents go to cyber cafes and at their friends' places for accessing computers. After cyber cafe and home, friends' place is the third preferred place visited by respondents. 27.5 per cent of the respondents used computers at multiple places which means that respondents were accessing it at cyber cafés, friends' place, home, and computer institutes. Only a few respondents accessed computers only at one place whereas the percentage of those who used it at more than one place is quite high. This is a very significant finding which suggests that it is not only the computer but the situation and environment that may even be more important for the adolescents. Working on a computer, may not be an end in itself for them, the surrounding and level of privacy being of even a greater relevance.

The data in Table 2 were then related with the income level of the families of respondents and presented in Table 3. 60 per cent of the respondents belonged to the lower income group, i.e. Rs -10,000 to Rs 20,000. In this income category, 24.5 per cent respondents possessed computers at home. Table 3.5 
shows that out of the total 24.5 per cent respondents who possessed computers at home, 23 per cent were accessing it both at home and at cyber café. This shows that possessing a computer at home and their economic status were not sufficient reasons to debar respondents from visiting cyber café. There were 32 per cent respondents who used it at cyber cafe and at friends' places. 28 respondents belonged to the income level of Rs 50,000+, out of which 12 respondents were accessing computer at home as well as at cyber café whereas 7 respondents accessed computers at multiple places. In the most affluent group, i.e. Rs. 50,000+, one would expect that almost all respondents would be possessing a personal computer, but it is surprising to see that only 04 respondents in this category were such who accessed computers only at home. whereas a majority were using it at multiple places. Similarly, in the lowest income group, a majority of respondents were using computers at multiple places. This raises the significance of the place at which computer is accessed. Thus, the data in Table 3 show that income level has no relation with the places

Table 3Distribution of Respondents According to their Family Income (p.m.) and Places at which they Access Computers

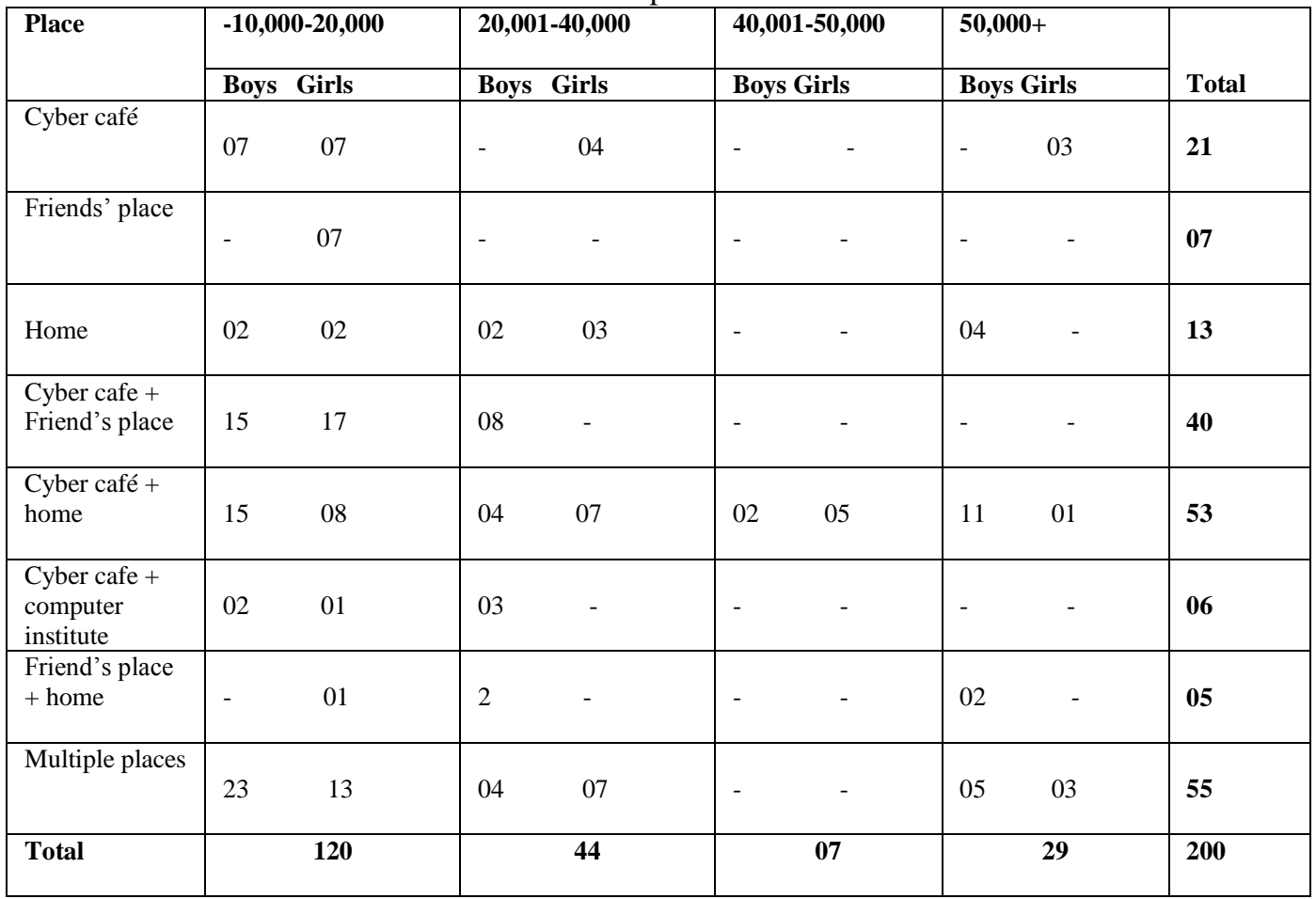

Used for accessing computers. Respondents belonging to different levels of income had been using all the four places for accessing computers.

As we have noticed in the previous data, cyber café is the place most frequently visited by respondents for accessing the computers. Respondents go to the cyber café they like the most, depending upon the facilities offered by it, like separate cabins, lower charges or a desirable location of the cyber café etc. Chandigarh is a planned city and it is planned in such a way that every sector has its own market. Apart from the other mundane services, all these markets have atleast one or often a number of cyber cafes. Certain markets in Sectors 15, 35, 11, 8, 32 and 40 have the maximum number of cyber cafes. Cyber cafés of Sectors 26 and 8 are the most spacious and sophisticated cafes in the town. There are some cyber cafes which provide additional facilities of pool and pub too. We can very well imagine the extent of competition among the cyber cafes. One of the owners of the cyber cafes in Sector 15 narrated that his business had suffered in the past since he was not offering separate cabins to the users. He revealed that he had to change the whole interiors of the cyber café according to the demands of the users, by making it fully air conditioned and with the provision of separate cabins. So this suggests that young computer users prefer private spaces while accessing computers.

Thus it becomes all the more important to know about the location of computers preferred by respondents. For instance, within home, one may have a computer in one's personal room where he/ she can enjoy complete privacy, or it may be placed in a common space which hardly gives any privacy to the user. Since our earlier data have clearly revealed that our respondents were visiting cyber cafes or friends' places for accessing computers, it was pertinent to know as to whether this was due to the lack of privacy they enjoyed at home in regard to the use of computers or there were some other reasons. Table 4 shows the location at which 
computers were used by respondents, i.e. at home or at friends' place. Data reveal that 58 per cent of respondents were using computers in a common space (like drawing room, lobby, master bed room etc.) whereas 42 per cent in a private space (personal room) at home. At friends' places percentages are exactly the opposite. There, 58 per cent accessed computers in the private space whereas 42 per cent had been using it in the common space. Thus, one can clearly infer from the data that what attracted respondents at friends' places was the private location of computer. The other two places i.e. cyber cafés and computer institutes are not discussed in the Table 4 as the computer institute is a common place where the batch mates share one computer sitting

Table 4 Location of Computers Used by Respondents

\begin{tabular}{|c|c|c|c|c|}
\hline \multirow[t]{2}{*}{ Location of computer } & \multicolumn{2}{|c|}{ Home } & \multicolumn{2}{|c|}{ Friends' Places } \\
\hline & Boys & Girls & Boys & Girls \\
\hline In common space & 40 & 24 & 23 & 17 \\
\hline In private space & 29 & 18 & 31 & 25 \\
\hline $\begin{array}{l}\text { Do not possess at home or do not } \\
\text { visit friends' place for accessing } \\
\text { computer }\end{array}$ & 42 & & 57 & \\
\hline Total & & 89 & 111 & 89 \\
\hline
\end{tabular}

In one computer laboratory whereas in the cyber cafe respondents preferred to visit those cyber cafes which provided privacy.

In a Medical Education Programme on adolescents' problems held on December 6, 2004 at Patiala, experts recommended that parents should not install televisions and computers in the bedrooms of their children. Rather, computers should be installed in a common area so that access to the internet could be monitored (The Chandigarh Tribune, December 7, 2004:5). David Marshall (1997) argued that children's bedrooms present a whole new set of anxieties that again operate in the particular middle class fraction of culture. The bedroom is a complex enclave of security, pleasure, vulnerability and privacy. Thus, it can be inferred that preference for privacy is one of the primary reasons that does not debar users from visiting cyber cafés even if they possess these at home. Besides privacy, another reason for going to cyber cafés by the respondents was availability of internet facility at cheaper rates. Respondents wanted to enjoy and entertain themselves by spending less money. Many respondents did not have internet connection at home as it would increase their telephone bills. One of the respondents said that while sitting in a cyber cafe one had to pay according to the time spent, whereas at home one kept on using it without realizing the time spent. So, cyber café is preferred to keep a check on one's pocket.

Besides the location of the computer (common or private), location of the cyber cafés visited by the respondents was another significant variable. Respondents were choosy about the cyber cafes. They were not only using the cyber cafes located near their houses or near their schools but were largely also using those cyber cafes located in different markets and interestingly, they were using more than one cyber cafe. Table 5 presents data on the location of the cyber cafés which were being visited by respondents and the data highlight that 74 per cent of the respondents did not visit any particular cyber café. They were using the cyber cafes located in markets of different sectors and schools depending upon their choice. This choice was based on the money charged by the cyber cafe for

Table 5 Distribution of Respondents According to the Location of the Cyber Cafés Visited by them

\begin{tabular}{|l|c|c|c|}
\hline Location & Boys & Girls & Total* \\
\hline Near school & 30 & 37 & 67 \\
\hline Near residence & 67 & 35 & 102 \\
\hline Not fixed** & 79 & 46 & 125 \\
\hline
\end{tabular}

* the categories are not exclusive

** not fixed here means respondents were using different places.

using the net per hour, apart from its ambience, crowd etc. 40 per cent of the respondents were accessing computers in cyber cafés which were located near their schools. Researcher also visited various cyber cafés of the city especially near schools and in the main markets and found both boy and girl students in their school uniforms in the cyber cafés. Table 5 also shows that more male respondents were using different locations of cyber cafés than their female counterparts. 
So, it did not matter to the respondents even if they had to go to a distant place for using internet. "What matters is the 'facilities' and 'gentry", remarked one respondent. "How one feels if one is sitting in a chair imported from Italy and computers from Taiwan. How it sounds, when while surfing web, one is enjoying coffee, tea, sandwich, burger and soft drinks", remarked another user. These are the services which a popular cyber cafe of Chandigarh provides to its clients. According to the manager of a cyber café, "cyber plus cafeteria, providing 19 " screen, air conditioned ambience, sitting arrangement, speed of the net, girls wearing short skirts and pants, coming in luxury cars, is the pull of cyber cafe'". So, it is not actually the internet services that attract the young adolescents but the kind of people sitting around, the luxuries at hand, and so on, that makes a place worth visiting.

Out of the total sample there were 84.5 per cent respondents who used to visit cyber cafés. Table 6 presents the data on the respondents' visits to cyber cafés. There were 54 per cent respondents who used to visit cyber cafés daily for accessing computer and 23 per cent of these daily visitors were

Table 6Distribution Of Respondents According To Frequency Of Visits To Cyber Cafes

\begin{tabular}{|c|c|c|c|c|c|c|c|c|}
\hline \multirow[t]{2}{*}{ Frequency } & \multirow{2}{*}{$\begin{array}{c}\text { Do not } \\
\text { visit }\end{array}$} & \multicolumn{2}{|r|}{ Daily } & \multicolumn{2}{|c|}{ Alternate days } & \multicolumn{2}{|c|}{ Once in week } & \multirow{2}{*}{ Total } \\
\hline & & Bo & Girls & & Girls & Boys & Girls & \\
\hline Internet at home & - & 10 & 11 & & 09 & 13 & 03 & 52 \\
\hline $\begin{array}{l}\text { No internet at } \\
\text { home }\end{array}$ & - & 16 & 04 & 06 & 03 & 03 & - & 32 \\
\hline No computer & - & 24 & 27 & 17 & 14 & 01 & 02 & 85 \\
\hline $\begin{array}{l}\text { Do not visit cyber } \\
\text { café }\end{array}$ & 31 & & - & & - & & - & 31 \\
\hline Total & 31 & & 92 & & 55 & & 22 & 200 \\
\hline
\end{tabular}

having internet connections at home. There were 33 per cent respondents who made use of cyber cafes for accessing computers on alternate days and out of these visitors 56 per cent had no computer at home. 13 per cent respondents visited cyber cafés only once a week and of these 72 per cent had an internet connection at home. More female respondents were visiting cyber cafés daily and were not possessing computer at home. Majority of these female respondents belonged to the low income groups. It is quite obvious that those who do not have computer or internet facility at home, make use of cyber cafes but our data highlight the opposite trend too. Thus, the lack of internet connection at home hardly keeps the people away from the cyber cafés. I tried to find out why it was so. On being asked, it is the 'purpose for which people use computers in the cyber café' remarked one respondent. Thus, this Table brings very important and noteworthy findings. Firstly, possessing a computer and an access to internet at home is not restricting the respondents' visits to cyber café. Secondly, respondents who had internet at home were visiting cyber café daily and those who were not possessing computer were visiting cyber café on alternate days.

Computers require hours of trial and error experimentation, a kind of extended play demanding a prolonged leisure time. Fully exploring the internet demands a lot of time for lengthy downloading, and patience with connections that are busy, so much so that some have dubbed the world wide web as the world wide wait. To gauge the effects of computer use, it is very important to know how much time adolescents spend with the medium. Time spent on computers varies from person to person. It also varies according to the place one is using for accessing computers like cyber café, friends' place or home. It is also related with the time of day and company preferred by the users. It was difficult for our respondents to respond to this question as they were using it at multiple places. Time given in Table 7 shows the approximate total time spent by the respondents daily at different places and possession of computers at home. Table 7 shows that 62 per cent of the respondents accessed computers for more than 2 hours a day. On the whole, male respondents were relatively heavy users as compared to female respondents as 69 per cent of the former sat before the computers for more than two hours daily. 29 per cent of the total respondents accessed computers for 1-2 hrs. daily and the proportion of female respondents was more in this case as compared to the male respondents. There were 20 per cent male respondents who used to access computers for more than 4 hours a day. Thus boys outclass girls in spending time with computer. There were 
Table 7 Distribution of Respondents According to possession of and the Time Spent on Computers

\begin{tabular}{|c|c|c|c|}
\hline \multirow{2}{*}{$\begin{array}{l}\text { Time spent } \\
\text { ( per day) }\end{array}$} & Possess computer & Do not possess computer & \multirow{2}{*}{ Total } \\
\hline & Girls & Boys & \\
\hline $1-2 \mathrm{hrs}$. & 13 & 10 & 58 \\
\hline $2-3 \mathrm{hrs}$. & 09 & 12 & 53 \\
\hline 3-4 hrs. & 15 & 09 & 39 \\
\hline More than $4 \mathrm{hrs}$. & 08 & 02 & 32 \\
\hline Not fixed (depends) & 06 & 04 & 18 \\
\hline Total & 111 & 89 & 200 \\
\hline
\end{tabular}

9 per cent respondents who said 'it depends'. By that they meant if they were watching any movie it could take more time, if they are playing some game and the game is interesting again it will take a longer time. So 'it depends' was related with the 'purpose' for which respondents were using computers. Data shows that there were 16 per cent respondents who accessed computers for more than 4 hours daily. On the whole male respondents were spending more time with computers as compared to female respondents. This Table reveals a clear association between the time spent and possession of computers by respondents. As the time spent with computers increases, the proportion of respondents with a personal computer increases and vice versa. This also shows that the respondents who possessed computers had an access to computers for 24 hours.

According to one cyber owner when a respondent says, 'it depends', it implies the user's purpose for accessing the net and company preferred by the user. He disclosed that if a boy was with his girl friend, he would take around two hours, if one was a professional doctor, engineer, advocate, etc. he would take more than three hours whereas college going students have no limits. He also mentioned that 50 per cent of their business is dependent upon school going and college students. Recent research on internet usage suggests that time spent on the net displaces time spent on other media, particularly television. Television viewing suffers because a great deal of internet usage is during the evening hours, when people traditionally watch TV (Weaver 1998).

We asked our respondents regarding the time of the day they spent with computers. Table 8 shows that 60 per cent of the respondents were accessing computers in the evening, i.e. after their school hours. 36 per cent respondents were using it in the afternoon, 19.5 per cent had an access at night and 5 per cent were accessing in the morning. 10 per cent respondents did not specify any fixed time for accessing computer. They used it any time they felt like.

Table 8 Distribution of Respondents According to the Time of the Day they spend on Computers

\begin{tabular}{|l|c|c|c|}
\hline Time of day & Boys & Girls & Tota** \\
\hline Evening & 65 & 56 & $\mathbf{1 2 1}$ \\
\hline Afternoon & 42 & 30 & $\mathbf{7 2}$ \\
\hline At night & 25 & 14 & $\mathbf{3 9}$ \\
\hline Any time & 13 & 07 & $\mathbf{2 0}$ \\
\hline Morning & 07 & 03 & $\mathbf{1 0}$ \\
\hline
\end{tabular}

*the categories are not exclusive.

Respondents reported that they downloaded music, screensavers etc. from the internet at night. Another respondent said 'I cannot get ready in the morning without listening to songs on computer'. One respondent reported 'my computer remains on almost the whole day, whenever I want to use it I can, without wasting any time'. Those who used it at night had different reasons like 'everybody goes off to sleep', 'internet charges are less', 'more speed' etc. Both male as well as female respondents were using it more frequently in the evenings when they were relatively free, 'it's a nice change' they reported. Even the cyber owners reported that the peak hours consisted of evenings and afternoons when maximum adolescents came in groups. There are cyber cafés which do not allow more than two users on one computer. Reason for not allowing more than two users as cited by the cyber owners was that it harmed their business. Secondly, cabins were not spacious enough to accommodate more than two users. Thirdly, when friends sat together, they discussed the sites, talked and sometimes laughed too loudly causing discomfort to other users sitting in the café. In short, the bahaviour of the owners of these cafes was governed primarily by commercial priorities and nothing else. For them it was business, their aim being the maximization of profit. 
Going to cyber café daily and sitting for hours together means paying heavy amount to the cyber owner. Initially cyber cafes were charging Rs 100 per hour. It came down to Rs 75 per hour, and then further down to Rs 60 and then to Rs 50 per hour. As more and more cyber cafes have come up in the markets and there is an easy access to this facility, the charges roll between Rs 15 to Rs 30 per hour. Internet charges of cyber cafes keep on fluctuating depending upon the competition in the market. Some of the cyber cafes have started offering packages to its users which range from Rs 100 to Rs 3000, For instance if a cyber cafe is charging Rs 25 per hour, and can make Rs 125 for 5 hours, instead of charging Rs 125, it offers a scheme to the clients ' 5 hours in just Rs 100', i.e. one hour free. The users buy this scheme but the condition for this scheme is that one has to consume the card within 5 days. So, in order to use the scheme, some of the users keep on visiting the same cyber cafe daily and sit for hours together without any specific work and consume the scheme before the stipulated time. These are the strategies which the community of cyber cafes is adopting in order to make more business and keep their customers glued to them.

Initially computer was hailed as educational, it was something which one had to learn from a specialized agency, e.g. a computer institute. Before the growth of cyber cafes, computer institutes were much in demand and were providing various courses which had a good weightage in the employment market. But now days, one learns it on his own while sitting at home and as far as basic knowledge of computer is concerned schools have introduced computers as one of the subjects. Some do join computer courses for learning basics but now students prefer the professional courses run by universities or reputed government owned institutes. Nowadays if one has to appear in any kind of interview, one is asked "do you know how to use computers"?

For respondents possessing computers, it was not something new and different. They found it normal to have a computer at home, but their routine conversation about computer revolved around the new advancements and various attachments of the computer. For instance - Do you have a laptop? Do you have a wireless mouse, an optical one or a simple? Is your computer Pentium 4 or 5 ? How much is the GB or MB of your computer? Is the keyboard simple or with multimedia attachments? Do you have a scanner, webcam, UPS, speakers etc.

To use computer and internet does not mean that you only require a machine, you need electricity, telephone connection, service provider, etc. and cyber cafes take a lead in providing these services. This is also one of the reasons of the sudden growth in cyber cafés and computer institutes which attracted the attention of everyone, especially the adolescents. It is not only the computer institutes and cyber cafes that are promoting the use of computers but schools too are providing computer training to the students. Some respondents had received computer training from their respective schools in or before class $10^{\text {th }}$ but others had learnt it on their own. Respondents came from different schools and represent different socio economic backgrounds. In the above discussion we have seen an association between socio economic variables and the possession of computers by the respondents. Whether respondents were from Government school or from a Private, whether they belonged to Low class or Upper that had no association with the nature of access to computers. Cyber cafés and friends' place were the most popular locales for accessing computers. Privacy was the common reason cited by respondents for visiting cyber cafés and friends' places. Respondents were choosy in the selection of the location of cyber cafés and the time of the day they used to spent with computers. Our respondents love to be with the company of computers, as evidenced by how much time they spend with them. It is clear from the discussion that computers and internet are an extremely important part of adolescents everyday lives. The various service providers realize this and continue to provide more and more at cheaper rates to attract the most vulnerable population-adolescents. The most significant observation reflected through the data in this paper is that the popular assumption that 'computer is an end in itself' is a myth. The commonly held belief that a child needs a computer for better information and education and thus must be provided one at home, is a misnomer. Computer, our findings show, is only a machine, a means, which is not an end in itself. On the contrary, what adolescents are more concerned with is where the computer is located, with whose company he/she would be using it etc. It is possible that this is particularly true in the case of adolescents who are getting initiated into the computer world, accompanied by huge fantasies of forthcoming youth, adulthood and sex stories, so that they perceive computer not merely as a tool of information but much more than that. For adults on the other hand, computer may be a tool which they can use to meet their objectives- both academic, and professional. Hence our data show that adolescents' whole conception of a computer is different, irrespective of which socio- economic category they belong to and which family background they come from. Most of our respondents, whether rich or poor, from government or private schools, with or without personal computers at home, were using the machine at multiple places, which indicates that more than the computer, it is the location and the environment which are more important to them.

Our computer driven society demands that youth must develop the ability to operate in a technological environment. In response to these demands young adolescents have very easily and speedily adapted themselves. Not only they have learnt to operate this machine but they have raised a few conditions before they hang out on it. Their preference for 'perfect ambience' and private space has further left us with some questions. For what purpose do the adolescents use computers? Is it worth to buy one for the children? Out of the time 
spent on Internet how much exactly is devoted to educational purpose? Are computers really good for the adolescents? The present paper leaves the scope for further exploration of this issue and introspection of the members of society to fix the responsibility to guide the adolescents to tread the right path.

\section{References:}

[1]. Buchner, P., M. D. Bois-Reymond and H.-H.Kruger, 1995, 'Growing Up in Three European Regions', in L. Chisholm (Ed.), Growing Up in Europe: Contemporary Horizons in Childhood and Youth Studies, pp. 43-59. Berlin: de Gruyter.

[2]. Centre for Media Education, 2001, 'A Report on Web Site Compliance', Washington:DC.

[3]. Giddens, A., 1991, Modernity and Self-Identity: Self and Society in the Late Modern Age. Cambridge: Polity Press.

[4]. Gray, Ann, 1989, 'Behind Closed Doors: Video Recorders In The Home' In H.Bacher \& G. Dyer (ed.), Boxed In: Women And Television, London:Routledge \& Kegan Paul.

[5]. Hope, A., 2007, 'Risk Taking, Boundary Performance and Intentional School Internet "Misuse", Discourse 28(1): 87-99.

[6]. Kawamoto, K. 2003, Media and Society in Digital Age, Boston: Allyn \& Bacon.

[7]. Kerr, M.H. Stattin, 2000, 'What Parents Know, How They Know it, and Several Forms of Adolescent Adjustment: Further Support for a Reinterpretation of Monitoring', Developmental Psychology, 36(3): 366-380.

[8]. Lehart, A., Rainie, L. \& Lewis, O., 2001, 'Teenage Life online. The Rise of Internet Message Generation and the Internet's Impact on Friendships and Family Relationships', Washington DC: Pew Internet and American Life Project.

[9]. Liau, A. K., A. Khoo and P. H. Ang, 2005, 'Factors Influencing Adolescents' Engagement in Risky Internet Behavior', Cyber Psychology \& Behaviour 8(2): 513-520.

[10]. Livingstone, Sonia, 2008, Taking Risky Opportunities in Youthful Content Creation: Teenagers' Use of Social Networking Sites for Intimacy, Privacy and Self-expression. New Media \& Society, 10 (3). pp. 393-411

[11]. Lyman,P. \& Varian,H.R., 2003, 'How Much Information?' in Potter, James, 2008, Media Literacy, $4^{\text {th }}$ edition, Sage:London.

[12]. Marshall, David, 1997, 'Technophobia : Video Games, Computer Hacks And Cybernetics', cited in Media International Australia, No.85, Nov. pp70-8

[13]. Potter, James, 2008, Media Literacy, $4^{\text {th }}$ edition, Sage:London.

[14]. The Kaiser Family Foundation's Recent Report, 'Kids And Media @ The New Millennium’ by Dr. Ellenwartella, Dr. Barbara o'Keefe And Dr. Ronda Scantlin, in www.kfff.org

[15]. Wazcman,J.1991, Feminism Confronts Technology, Sydney: Allen \& Unwin,

[16]. Weaver, A., 1998. 'Net Worth', Working Women ,23(1), 20.

[17]. Wolak, J., K. J. Mitchell and D. Finkelhor, 2006, Online Victimization of Youth: Five years Later, University of New Hampshire: National Center for Missing and Exploited Children, Durham, New Hampshire. 